\title{
The viral agents of Acute Encephalitis Sydrome in Ben Tre province 2008-2010
}

\author{
Tran Ngoc Huu*, Luong Chan Quang, Do Kien Quoc, Phan Van Tinh, Huynh Thi Kim Loan, \\ Nguyen Thi Thanh Thao, Phan Van Tu, Vu Thi Que Huong \\ From Institut Pasteur International Network Annual Scientific Meeting \\ Hong Kong. 22-23 November 2010
}

Since 2005, Arboviruses and Enteroviruses have been confirmed as some of pathogens causing acute meningoencephalitis in children in the South of Vietnam. Therefore, they have been selected in priority into a sentinel surveillance and investigation system of emerging infectious diseases in Ben Tre province during 2008-2010. The surveillance system for viral Acute Encephalitis Syndrome (AES) was established in 02 sentinel hospitals in Ben Tre province, Vietnam. All AES cases with macroscopic appearance corresponding to viral AES were enrolled into the surveillance. Their specimens (CSF, paired sera and feces) were only collected after patients or their legal guarantees had signed in the written ICF. The second serum of paired sera was collected on the field in case patient had discharged. MAC-ELISA was applied for detecting Arboviruses (such as Japanese encephalitis virus and Dengue viruses), and RT-PCR was used for detecting Enteroviruses, especially Enterovirus type 71.

From August 2008 to June 2010, 138 AES cases were enrolled into the surveillance system with 138 CSF, 276 sera and 138 feces specimens. Out of 138 reported cases from the surveillance system, 60 (43.48\%) AES cases had positive testing results with viral agents, including: 7 (5.07\%) Japanese encephalitis virus, 6 (4.35\%) Dengue viruses, and 47 (34.06\%) Enteroviruses. No case of infecting Enterovirus type 71 was detected. Epidemiological analysis shown that Enteroviruses circulated all year round, Dengue viruses circulated from August to October in accordance to the Dengue epidemic season in the South of Vietnam and Japanese encephalitis virus circulated sporadically in a year. Moreover, distribution of viral agents specific by age groups shown that age

Pasteur Institute of Ho Chi Minh City, Vietnam

Full list of author information is available at the end of the article group of $0-14(11.76 \%)$ and over $60(18.18 \%)$ were the most susceptible for infecting Japanese encephalitis virus.

The surveillance system has provided valuable information as a baseline for future studies on viral agents of AES and for implementing Japanese encephalitis vaccination campaigns in Ben Tre province. The implementation in reality also raised the needs of developing and applying diagnostic tests with high sensitivity and specificity such as NS1 antigen detection for Japanese encephalitis virus and multiplex RT-PCR for Enteroviruses.

\section{Acknowledgements}

Supported by the French Development Agency through the Surveillance and Investigation of Epidemic Situations in Southeast Asia (SISEA) project.

Published: 10 January 2011

doi:10.1186/1753-6561-5-S1-P115

Cite this article as: Huu et al:: The viral agents of Acute Encephalitis Sydrome in Ben Tre province 2008-2010. BMC Proceedings 2011 5(Suppl 1):P115.

Submit your next manuscript to BioMed Central and take full advantage of:

- Convenient online submission

- Thorough peer review

- No space constraints or color figure charges

- Immediate publication on acceptance

- Inclusion in PubMed, CAS, Scopus and Google Scholar

- Research which is freely available for redistribution

\section{Biomed Central}

(c) 2011 Huu et al; licensee BioMed Central Ltd. This is an open access article distributed under the terms of the Creative Commons Attribution License (http://creativecommons.org/licenses/by/2.0), which permits unrestricted use, distribution, and reproduction in any medium, provided the original work is properly cited. 